\title{
O teatrze science fiction kilka uwag
}

ABSTRACT. Dybizbański Marek, O teatrze ${ }_{n}$ science fiction" kilka uwag [Some remarks on the science fiction theatre]. "Przestrzenie Teorii” 7, Poznań 2007, Adam Mickiewicz University Press, pp. 215-235. ISBN 978-83-232177-2-5. ISSN 1644-6763.

The science fiction aesthetics has actually never created (formed) its own kind of drama and in spite of attempts undertaken several times it has not been feeling completely at home. Theoreticians (Theorists) of science fiction see the theatre as an inconvenient (troublesome) partner which "reveals the imitative character of the presented world and destroys the atmosphere of fantasticality". In the meantime the history of the science fiction drama reveals quite an astonishing regularity, namely it appears that the manner of creation of the science fiction stage illusion is completely independent of the degree of technical advancement of the theatrical machinery. The better the equipment of the theatre, the more modestly science fiction appears in it. Coexistence of fantasticality and theatricality in the works written for stage, however, does not occur without any conflict and is more often based on respecting of limitations (restrictions) resulting from the system rather than harmonious co-operation.

Pierwotny impuls dla podjęcia niniejszych rozważań dały dwa dramaty zachowane w archiwum Emila Zegadłowicza - Noc Amora Jana Planeckiego i anonimowa Wyprawa $w$ zaświaty. Utwory grafomańskie, dowodzące wszelako popularności tematyki futurologicznej i dające pojęcie o rozległości wyobrażeń międzywojennej epoki, którymi żywiła się „futurologizująca" literatura dramatyczna od naukowych komedii Winawera, poprzez społeczno-obyczajowe wariacje Rostworowskiego (Miłosierdzie, Straszne dzieci), Zegadłowicza (Eyżki i księżyc), Pawlikowskiej-Jasnorzewskiej (Kochanek Sybilli Thompson), aż po sceniczne prezentacje katastroficznej filozofii Witkacego (Szewcy).

Noc Amora skonstruowana jest wokół sceny tytułowego obrzędu spełnianego w teatralnej konwencji dziewiętnastowiecznej dramy czarodziejskiej o rodowodzie barokowym. Chwyt ten przypomina zastosowanie konwencji operowej do przedstawienia obozu rewolucji w III części Nie-Boskiej Komedii. Podobnie zresztą jak w dramacie Krasińskiego - w tej scenie najwyraziściej objawia się organizacja przyszłego świata, w którym Król Ludów Ziemi realizuje program naprawy świata i człowieka poprzez wyhodowanie nowej rasy, czyli zastąpienie przypadkowego doboru naturalnego naukowo opracowaną selekcją. Sceniczne efekty są tu jednak do treści sceny bardziej nieudolnie "przyfastrygowane" - chyba że założyć, iż cała sztuczność tej oprawy obnażać ma właśnie nieudolność, z jaką Król próbuje zasłonić ohydę swojego pomysłu. Są więc śpiewy, 
a przede wszystkim tańce mutantów - grupowe i indywidualne, swobodne i reżyserowane przez Ministra Zabaw Ludowych „w kostiumie baletmistrza, z małymi skrzydełkami u ramion”, pojawia się nawet „Chłopczyk w postaci bożka Amora”, który "trzymając w ręku łuk i kołczan opuszcza się z góry przy pomocy linki i obrzuca pary miłosne żywymi kwiatami"2, po czym zamyka pierwszy akt sztuki wypuszczeniem strzały w stronę Złotowłosej i Króla.

Mimo że dramat powstał z myślą o teatrze raczej dobrze wyposażonym (wpisano weń nawet projekcję filmową wraz ze zgodą na jej usunięcie, gdyby przekraczała możliwości teatru), techniczny aspekt przyszłej organizacji świata reprezentowany jest tu skromnie. Wątpliwości i wahania autora, dotyczące maszynerii teatralnej, koncentrowały się wokół innego rodzaju efektów, niż by można oczekiwać po widowisku $\mathrm{z}$ „bardzo a bardzo dalekiej przyszłości”. Futurologiczną treść uatrakcyjniać miała właśnie sceniczna oprawa $z$ odległej przeszłości. Dobitnie wyraża ten zamysł wstępne Objaśnienie:

Jako nowy, konkurencyjny czynnik dla kina wprowadzono: balet, śpiewy, świetlne obrazy, dające się $w$ mniejszym lub większym stopniu stosować, zależnie od uzdolnień aktorskich, a także finansowych i technicznych sił teatru ${ }^{3}$.

Wybór konwencji scenicznej był zatem świadomy. I dla futurologicznej sztuki historycznie usprawiedliwiony. Ale tylko historycznie, gdyż teatr czarodziejskiej dramy już od pół wieku (czyli już od czasów poprzedzających tzw. wielką reformę teatru) uchodził za przeżytek ${ }^{4}$. Jaka zak. 19.

1 J. Planecki, Noc Amora, rkp. Biblioteki Uniwersyteckiej UAM, sygn. 3870/3,

2 Tamże, k. 27.

3 Tamże, k. 3.

${ }^{4} \mathrm{U}$ progu lat siedemdziesiątych XIX wieku prasa poznańska chłodno przyjęła wystawienie Chtopa milionowego Ferdynanda Raimunda:

„Przede wszystkim idzie nam o to, żeby teatr polski istniał w Poznaniu i byt swój stanowczo utrwalił a potem dopiero wszelkimi środkami wpływać będziemy na kształcenie się repertuaru i wyrabianie sił artystycznych. [...] Dyrekcja np. potrzebuje środków do prowadzenia sceny; jeżeli tedy publiczność nie przysparza jej takowych, uczęszczając nielicznie na przedstawienia dramatyczne i dobrych komedyi, to kierownik sceny uciekać się musi do dawania śmiesznych fars i tak banalnych melodramatów jakim jest $C h$ to $p$ mili i nowy Raimunda, przerobiony a raczej nędznie przetłumaczony p[rzez] Józefa Damse. Alegoryczny ten melodramat w 3-ch aktach jest w dzisiejszych czasach anachronizmem scenicznym, teatr jednak przez wieczór sobotni i wczorajszy był literalnie przepełniony. Dla tylko co przytoczonych powodów nie robimy dyrekcji najmniejszego wyrzutu za ten wybór a notujemy tylko ogólną zasadę, którą dopiero w przyszłości stosować będziemy, że jeżeli teatr ma być istotnym przybytkiem sztuki i godnie zachowywać się na swojem wplywowem stanowisku, za to smak publiczności wyrabiać, nie za[s] jej zachciankami kierować się powinien.” (Dziennik Poznański”, 14 lutego 1872). 
tem konwencja teatralna byłaby odpowiednia dla dramatu futurologicznego? Dyskusja na ten temat - gdyby ktoś ją zechciał wtedy otworzyć - ciągnęłaby się zapewne do dziś, nie przynosząc zadowalających rozwiązań, podobnie jak spory o gatunkowe wyznaczniki i granice epickiej fantastyki naukowej. Estetyka science fiction nigdy właściwie nie wykształciła własnej odmiany dramatu i nie zadomowiła się w teatrze z kilkoma wyjątkami traktowanymi przeważnie jako potwierdzenie reguły. Fakt ten literatura przedmiotu stara się pomijać lub tłumaczy trudnościami technicznymi, więc teatralność fantastyki naukowej nie istnieje nawet jako problem teoretyczny, a podręcznikowe i encyklopedyczne opracowania stają się z konieczności świadectwem bezradności swych autorów wobec tego zagadnienia. Wydaje się znamienne, że w $L e-$ ksykonie polskiej literatury fantastycznonaukowej Andrzeja Niewiadowskiego i Antoniego Smuszkiewicza hasło "dramat” - tradycyjnie łączone $\mathrm{z}$ teatrem - omówione zostało w opozycji wobec form "wygodniejszych", jakimi są w dziedzinie literatury gatunki epickie, a w dziedzinie teatru... słuchowisko radiowe.

Forma słuchowiska nie wymaga bezpośredniej prezentacji, odwołuje się do wyobraźni słuchacza i dlatego częściej i z większym powodzeniem może wykorzystywać konwencję fantastyki naukowej5.

Teatr - zdaniem autorów Leksykonu - „z całą bezwzględnością ujawnia imitacyjny charakter świata przedstawionego i niszczy atmosferę fantastyczności"6. Zarzut ten - paradoksalnie, w sytuacji podkreślenia wyższości radia - sugeruje, że widowisko fantastycznonaukowe jest

Dowodem popularności nowej - odpowiedniejszej dla science fiction - estetyki może być za to oszałamiający sukces sztuki Julesa Verne'a i Adolphe’a Dennery Podróż naokoło ziemi $w 80$ dniach.

W lutym 1876 roku „Dziennik Poznański” zapowiadał „przedstawienie Podróży naokoło świata, która, gdzie tylko była przedstawiana, gromadziła licznie publiczność, a powtarzano ją wszędzie co najmniej po kilkanaście razy, były nawet miasta, gdzie ją kilkadziesiąt razy przedstawiano, a zawsze przy natłoku publiczności” (,Dziennik Poznański”, 8 lutego 1876, nr 30). Dekoracje „sprowadzone umyślnie z Wrocławia” („Dziennik Poznański”, 12 lutego 1876, nr 34) opisała w pamiętniku Paulina z Mottych Cegielska:

„Czegóż w tym przedstawieniu nie było! Pociąg w zmniejszonym formacie wjeżdżal na tle skalnych dekoracji już w normalnej postaci na scenę, na której czerwonoskórzy Indianie czatowali z łukami w ręku na podróżnych nieswiadomych grożącego im niebezpieczeństwa. To znów w świętym gaju pełzały cętkowane węże i przewalając swe ociężałe cielska wśród drzew, spuszczały się do miseczek z mlekiem, którym poiły je biało odziane westalki pogańskie" (P. Cegielska, $Z$ moich wspomnień. Przechadzki po mieście, cyt. za: L. Trzeciakowski, "Cacko i pieścidetko" - Teatr Polski 1875-1918, „Kronika Miasta Poznania" 2000, z. 3, s. 125).

5 A. Niewiadowski, A. Smuszkiewicz, Leksykon polskiej literatury fantastycznonaukowej, Poznań 1990, s. 262.

${ }^{6}$ Tamże. 
w ogóle nie do pomyślenia w teatrze słowa, gdyż realizować się może jedynie poprzez obraz, a ponadto pozostaje w zgodzie z tymi teoriami, które zakładają możliwość definiowania fantastyki naukowej tylko w obrębie doktryny realistycznej. (To prawda, że groteska może z kolei fantastykę doszczętnie rozsadzić, ale taka już jej wredna natura, że rozsadza wszystko, a w opowiadaniach Lema obie kategorie przecież jakoś funkcjonują ${ }^{7}$ ).

Prymat realizmu dochodzi do głosu chociażby w definicyjnej propozycji Antoniego Smuszkiewicza, który za wyznaczniki gatunku proponuje uznać motyw fantastycznego środka technicznego i myślenie o pozorach naukowości, a jako najczęstsze - choć niekonieczne - dodatki konstrukcyjne wskazuje elementy zapożyczone $\mathrm{z}$ gatunków wcześniejszych, takie jak rozwiązania motywacyjne rodem $\mathrm{z}$ baśni (np. niejasne zasady działania skomplikowanych automatów), motywy podróży i schematy wartkiej akcji, pochodzące $\mathrm{z}$ powieści awanturniczej oraz przejęte $\mathrm{z}$ utopii obrazy idealnych światów bądź - $\mathrm{z}$ antyutopii - ich negatywy ${ }^{8}$.

Wszystkie te "przeszczepione" dodatki zna również historia dramatu, jakkolwiek uchodzą one $\mathrm{z}$ reguly za niedramatyczne rozwiązania wprowadzane $\mathrm{w}$ rezultacie romantycznego zanieczyszczenia gatunków. Podstawowa definicja jednak - mimo że i tak stosunkowo liberalna ${ }^{9}$ pomieściłaby w sobie bodaj tylko naukowe komedie Winawera i może niektóre utwory dramatyczne Lema (ze względu na wehikuł profesora Tarantogi). Zawahać by się można przy Kochanku Sybilli Thompson, bo czy proces odmłodzenia Sybilli jest tam „wynalazkiem” dostatecznie umotywowanym naukowo, czy raczej sprawia, że fantastyka utworu ciąży ku baśniowości?

Innego rodzaju wątpliwości budzi - także podporządkowana realistycznej doktrynie - gatunkowa teoria Andrzeja Zgorzelskiego. Zasadza się ona na założeniu, że „pojawienie się fantastyki w utworze - to prze-

7 Zob. R. Handke, Groteska fantastycznonaukowa, w: Polska proza fantastycznonaukowa. Problemy poetyki, Wroclaw-Warszawa-Kraków 1989, s. 64-79.

${ }^{8}$ Zob. A. Smuszkiewicz, Zaczarowana gra. Zarys dziejow polskiej fantastyki naukowej, Poznań 1982.

9 Padały w historii badań nad literaturą science fiction propozycje radykalne. W pierwszym numerze czasopisma „Science Wonder Stories” (założonego w 1929 r.) Hugo Gernsback deklarował chęć publikowania tylko takich utworów, „które osadzone są na bazie praw naukowych w tej postaci, w jakiej je znamy, lub też na logicznej dedukcji tych praw w oparciu o naszą aktualną wiedzę". Jak zauważył Patrick Parrinder, powołana przez Gernsbacka grupa ekspertów musiałaby - w celu zadoścuczynienia założeniom pisma odrzucić nie tylko utwory Wellsa, ale i Frankensteina Mary Shelley [1818], uważanego tradycyjnie za pierwszą powieśc fantastycznonaukową. Zob. P. Parrinder, Science fiction a światopogląd naukowy, przeł. J. Kozak, w zbiorze: Spór o SF. Antologia szkiców i esejów o science fiction, red. R. Handke, L. Jęczmyk, B. Okólska, Poznań 1989, s. 355. 
łamanie ustalonych wcześniej w tekście praw świata przedstawionego"10. Jako przykład podaje Zgorzelski Niewidzialnego cztowieka Wellsa, gdzie „niewidzialność” tytułowego bohatera łamie „prawa świata fikcyjnego od początku powieści modelowane [...] na wzór tych, które rządzą światem realnym"11. I znów mogłoby się wydawać, że z całej literatury dramatycznej odpowiadają tej formule jedynie komedie Winawera, gdzie prawa świata konstruowanego realistycznie zakłóca jakiś „roztwór profesora Pytla” albo „promienie FF”. Rzecz się wszakże komplikuje w związku z koniecznością wyznaczenia osoby uprawnionej do rozpoznania faktu przełamania reguł. Za najbardziej wiarygodne uważa Zgorzelski „reakcje samych "mieszkańców” świata przedstawionego, a mianowicie postaci, które należąc do świata fikcji świadome są w pełni zasad założonego w nim porządku"12. Nadal najlepszym przykładem pozostają opowiadania o cudownym wynalazku, które na terenie dramatycznych form science fiction wydzielają się w osobną grupę wyraziściej chyba nawet niż w epice. Grają bowiem perypetią, a nie konstrukcją świata przedstawionego ${ }^{13}$, która jest tylko zakłóconym realizmem, a o charakterze fantastycznonaukowym tego zakłócenia przesądza fakt, że miksturę sporządził nie czarodziej, lecz profesor, albo że bohater stał się niewidzialny wskutek rozszczepienia cząstek materii organizmu zamiast nałożenia czapki-niewidki. W Promieniach FF Winawera szalony wynalazca Serafin sam oświadcza, że zakłóci realizm, zmieniając klimat za sprawą obrócenia kuli ziemskiej. Nie jest jednak jasne, który świat

10 A. Zgorzelski, Fantastyka. Utopia. Science fiction. Ze studiów nad rozwojem gatunków, Warszawa 1980, s. 21.

11 Tamże, s. 23.

12 Tamże, s. 22.

13 W tego typu utworach - wedle trafnego określenia Anny Krajewskiej - komedia „Zwycięża” naukę. „Temat nauki został wchłonięty przez komedię, ale równocześnie poddany presji reguł stylu niskiego. Gatunek nie ulegl całkowitym przeobrażeniom, nie zmienił się nawet na tyle, aby można było wyodrębnić go jako osobny typ tzw. "komedii naukowej». Na nowym temacie zaciążyły stare reguły gatunku. Chciałoby się powiedzieć, że komedia wygrywa z nauką" (A. Krajewska, Komedia polska dwudziestolecia mį̨dzywojennego. Tradycjonaliści i nowatorzy, Wrocław 1989, s. 36-37).

Sylwia Wójcikowa zauważa, że „tylko osobliwość tematyczna, która pozostaje w zgodzie z regułami gatunku, pozwala na wyodrębnienie tego rodzaju twórczości z całokształtu realistycznego melodramatu i komediofarsy [...] Technika komedii obyczajowej nawiązująca do tradycji bulwarowej komedii francuskiej, oscylująca między normą kompozycyjną piéce bien faite a piéce á these, podkreśla obowiązującą w tym gatunku zasadę wyakcentowania reguł, a nie różnorodności tworzywa dramatycznego. [...] Osobliwość komedii naukowych decyduje jednak o tym, że zamiast sytuacji dramatycznej związanej ze stereotypowym trójkątem małżeńskim mamy do czynienia z sytuacją dramatyczną wypełnioną problemem naukowym". (S. Wójcikowa, Swiat komedii naukowych $B$. Winawera i A. Cwojdzińskiego, „Przegląd Humanistyczny” 1979, z. 2, s. 134). 
przedstawiony powinien być uznany za właściwe „mieszkanie” postaci. Swiat realistycznie zrazu odtwarzanej Warszawy? Czy świat teatru, w którym „tropikalniejąca” Warszawa jest przedstawiana? Czy może świat techniki pisania sztuki dla teatru? Autotematyczne dygresje nieustannie podważają tu przecież wiarygodność postaci.

Wszakże i w przypadku utworów, w których nie dochodzi do tak silnego spiętrzenia poziomów komunikacji, sprawę skomplikować może już zwykła indywidualizacja postaci. Wystarczy spojrzeć na romantyczne sceny w domu obłąkanych lub sceny kontaktu ze światem nadprzyrodzonym. Struktura świata przedstawionego i przebieg akcji dramatu romantycznego skłaniają w zasadzie do przyznania racji wariatom, ale nie można przecież wykluczyć, że przez cały czas mamy do czynienia z przestrzenią indywidualną, projekcją stanów duszy bohatera'14. Już pisarze romantyczni stosowali podwójną wykładnię motywacyjną - mistyczną i realistyczną jednocześnie. Nawet wzloty Mickiewiczowskiego Konrada w relacji jednego $\mathrm{z}$ uczestników sceny - Kaprala - dają się tłumaczyć jako atak epileptyczny.

Nie trzeba zresztą zaraz odwoływać się do podwójnej wykładni ontologicznej i tak głębokiego psychicznie zróżnicowania postaci, by dostrzec problem kontrastu dwóch światów, obecnego przecież w najprymitywniejszych nawet realizacjach science fiction, ale i kilku innych odmian piśmiennictwa. Co prawda propozycja Zgorzelskiego zakłada i taką możliwość, że dopiero odkrycie świata ziemskiego wprowadza klimat fantastyki do utworu pisanego z perspektywy mieszkańca odległej galaktyki. Analogicznie zatem należy przypuszczać, że w świecie rządzonym przez wróżki fantastyka objawi się dopiero w chwili, gdy cudowny eliksir nie zadziała, a miotła nie wzbije się w powietrze. Ciągle jednak nie wiadomo, której postaci wypada wierzyć. Zgorzelski nie precyzuje bowiem, jaki procent bohaterów powinien doznać szoku w wyniku zakłócenia normy lub wręcz odkrycia nowego świata. Czy zaskoczenie powinni objawić wszyscy mieszkańcy Marsa, czy jeden mieszkaniec Ziemi, czy cała ziemska ludzkość odkrywana właśnie przez Marsjan, a wpisana w dzieło pod postacią idealnego odbiorcy (czytelnika bądź widza)? Gdyby przyjąć założenie, że wystarczy jeden zdziwiony bohater, wówczas pojemność proponowanej definicji drastycznie wzrośnie. Obejmie ona i Guliwera, i hrabiego Henryka w obozie rewolucji, i mieszkańca Europy zwiedzającego u Bacona „Nową Atlantydę", a także każdego mieszkańca antyutopii, który - jak Winston z Roku 1984 Orwella - za sprawą kontaktu ze świa-

14 Jan Błoński, definiując „zsubiektywizowaną” przestrzeń dramatów dwudziestowiecznych, przyznaje, że możliwości subiektywnej przestrzeni przeczuwali już chyba romantycy. Zob. J. Błoński, Dramat i przestrzeń, w zbiorze: Problemy teorii dramatu i teatru, wybór i opracowanie J. Degler, Wrocław 1988. 
tem przeszłości, poznawanego choćby tylko ze starych pamiętników i gazet - zaczyna „swój” świat obserwować oczami świata „innego”, wpisanego $\mathrm{w}$ dzieło dzięki porozumieniu autora $\mathrm{z}$ czytelnikiem ponad głowami postaci.

Ewolucja psychiczna takiego bohatera jest już zabiegiem dość wyrafinowanym, a trudnym do przeprowadzenia w dramacie, który ma jeszcze zaprezentować fantastyczny świat $\mathrm{w}$ zwartej akcji konstruowanej z dialogów i ograniczonej rozmiarami kilku aktów. Trudno się dziwić, że modelowana w ten sposób postać Inżyniera w Nocy Amora Planeckiego pozostała niedopracowana, skoro nawet Stanisław Lem zastosował w swych utworach scenicznych łatwiejszy konstrukcyjnie (choć zarazem kłopotliwy z uwagi na konieczność dodatkowych uzasadnień) chwyt „przerzucenia" bohatera $\mathrm{z}$ jednego (znajomego) do drugiego (obcego) świata. To przypadek profesora Tarantogi, który ze swojsko, z pełnym realizmem urządzonej pracowni wyrusza w podróż międzyplanetarną. W dramacie Leszka Proroka Powrót taty astronauta Adam Hust powraca na Ziemię po upływie kosmicznego kwartału, który równa się sześciu ziemskim dziesięcioleciom. Akcja rozgrywająca się po jego powrocie przypada na rok 2050, a więc chwila startu (1990 rok) była mimo wszystko bliższa potencjalnym widzom sztuki powstałej na początku lat sześćdziesiątych. Postępując za tym bohaterem widz rozpoznaje stopniowo w parze krzepkich staruszków jego dzieci i studiuje organizację świata przyszłości. W dramacie Pawlikowskiej tego rodzaju przewodnikiem pozostaje sama tytułowa Sybilla Thompson - starsza pani, która co prawda nie wylądowała w obcym sobie świecie nagle i niespodziewanie, ale bieg historii obserwowała raczej z boku, zachowując nie tylko pamięć, ale i poglądy i przyzwyczajenia czasów swej młodości, przypadającej na lata współczesne teatralnym widzom Kochanka (od natrętnej retoryki scen ekspozycyjnych, której nie uniknął nawet Karol Capek, obwołany ojcem dramaturgii fantastycznonaukowej, ocaliła utwór Pawlikowskiej zdwojona motywacja uczestników dialogu prezentującego reguły przedstawianego świata - po pierwsze obojętność młodego pokolenia, wnuków Sybilli, którzy są Chińczykom „wdzięczni za zajmowanie się Europą”, po drugie zaś normalna relacja międzypokoleniowa, zakładająca „niereformowalność” gderliwej babci). Za każdym razem więc rolę przewodnika dziwiącego się obcemu światu pełni postać konstruowana $\mathrm{z}$ zachowaniem reguł realizmu, bliska potocznemu doświadczeniu czytelnika bądź widza, która w istocie właściwych przewodników dopiero spotyka, pozostając raczej „pośrednikiem”, reprezentantem odbiorcy.

W sposób, który przywołuje na myśl wszystkie trudności związane $\mathrm{z}$ definicją realizmu, przeprowadza rozróżnienie rodzajów fantastyki Barbara Okólska. Warto pamiętać, że realizm jest pojęciem równie kło- 
potliwym definicyjnie jak fantastyka, a jego poetyka sformułowana już w punkcie wyjścia rozbija się o wewnętrzne sprzeczności - reguła prawdopodobieństwa kłóci się na przykład z wymogiem narratorskiej wszechwiedzy. Najbezpieczniej byłoby $\mathrm{w}$ zasadzie pozostać na poziomie banalnych potocznych stwierdzeń - tu przynajmniej wiadomo, że dywan, który lata pod wpływem zaklęć, jest baśniowy, dywan latający dzięki wszytym w niego mikroprocesorom będzie już fantastycznonaukowy, a dywan, który nie lata wcale, niezawodnie okaże się realistyczny. Każdy jednak rodzaj dywanu w obrębie językowej konstrukcji świata przedstawionego wikła się w skomplikowane zależności. Okólska przypomina, że „fantazja jest jednym z czynników twórczych charakteryzujących wszelkie rodzaje fikcji fabularnej, w tym również i tej, która obejmuje utwory urealistyczne»"15. Dają się jednak wyróżnić trzy sposoby konstruowania fikcyjnego świata: 1) „reprodukcja” empirycznej rzeczywistości pozaliterackiej w kreowanym świecie fikcyjnym, 2) „reprodukcja” skażona pewną deformacją (przez wprowadzenie elementów „niezwykłych”) i wreszcie 3) kreacja świata przedstawionego całkowicie odmiennego od empirycznych wzorców. W dalszych, szczegółowych analizach przywołuje Okólska klasyfikację Rogera Caillois, który sporządził najpełniejszą bodaj charakterystykę trzech odmian prozy imaginacyjnej (nierealistycznej) w perspektywie historycznej16. Trzy rodzaje utworów fabularnych wyznaczają w jego esejach trzy istotne „momenty zmieniającej się sytuacji człowieka na jego planecie"17. Początkowy podziw dla otaczającego a niezrozumiałego świata - krainy cudów i czarów - rodzi baśń z właściwą jej cudownością. Następnie duma zdobywcy planety (dzięki rozwojowi nauki $\mathrm{i}$ techniki) umożliwia powstanie fantastyki. Wreszcie z poczucia osamotnienia w przestrzeni kosmicznej i zagrożenia buntem robotów wyłania się literatura science fiction.

Baśń rozpoczyna się słowami: „Był sobie raz...” Rzecz w tym, że jej akcja rozgrywa się u zarania dziejów, w odległej i niedostępnej przeszłości, w świecie dawno minionym i zamkniętym. Opowiadanie fantastyczne zaczyna się tak samo jak każda powieść realistyczna, zdaniem w rodzaju: „23 lipca o godzinie 11.50 wieczorem na ulicy Humbolt $67 . . . ”$. Oznacza to, że sytuuje się ono w naszym świecie, wczoraj, dziś, w pierwszym lepszym mieszkaniu, co najmniej z pozoru, bo przecież niebawem wydarzy się tu cos strasznego. Science fiction ponownie wprowadza bezpieczny dystans, otchłań przyszłości albo, na jej miejsce, przestrzeni gwiezdnej. Ex definitione każda przedstawiana przez nią historia

${ }^{15}$ B. Okólska, $S F$, fantastyka, baśń, w zbiorze: $S p o ́ r ~ o ~ S F$, op. cit., s. 201.

16 Zob. R. Caillois, Od baśni do science fiction, w: Odpowiedzialność i styl, Warszawa 1967 oraz Science fiction, przedr. w antologii: Spór o SF.

${ }^{17}$ R. Caillois, Science fiction, w zbiorze: Spór o SF, s. 179. 
moglaby się zaczynać w sposób następujący: „Na Proximie Centauri...”, albo: „Będzie sobie raz...”, co wychodzi na jedno ${ }^{18}$.

Widać już teraz wyraźnie, że obawy autorów cytowanego wcześniej Leksykonu, dotyczące groźby zburzenia iluzji w teatrze, prowadzą w konsekwencji nie tylko do podważenia możliwości stworzenia widowiska fantastycznonaukowego. Grożą właściwie eksmisją ze sceny wszelkiego rodzaju fantastyce, unieważniając tym samym przebogatą tradycję teatralną, $\mathrm{z}$ antycznym chwytem deus ex machina włącznie (mimo że genetycznie nic on $\mathrm{z}$ fantastyką nie mial wspólnego).

Tymczasem historia dramatu science fiction (sam Niewiadowski przy innej okazji wymienia jednak parę utworów tego typu ${ }^{19}$, a i Lesław Eustachiewicz w swej historycznoliterackiej syntezie dramatu współczesnego wydziela je w swoistą, mało wiele zwartą grupę ${ }^{20}$ ) nie dość, że wykazuje próżność tych obaw, to jeszcze ujawnia zaskakującą prawidłowość okazuje się mianowicie, że sposób kreowania fantastycznonaukowej iluzji scenicznej pozostaje całkowicie niezależny od stopnia technicznego zaawansowania teatralnej maszynerii. Warto na dowód przytoczyć wstępne didaskalia dwóch futurologicznych utworów scenicznych, pochodzących $\mathrm{z}$ bardzo od siebie odległych $\mathrm{w}$ historii teatru epok.

U progu XIX wieku Karl Meisl, autor szeregu dram czarodziejskich, do których - pod względem światopoglądowym w całości, a technicznym częściowo - należy także cytowana sztuka, tak wyobrażał sobie sceniczny obraz przyszłego (dwudziestego) stulecia:

Teatr przedstawia przedmieście, przed namiotem, na którym jest napis „Parowo-Powietrzny Instytut" - stoi stolik, na nim gazety. - [...] Za podniesieniem kurtyny widać w głębi za sztachetami plug parowy orzący bez pomocy koni, na nim siedzi wieśniak i czyta książkę. - Dwa balony z przeciwległych stron przelatują przez scenę, słychać w górze głosy kolonistów ${ }^{21}$.

W roku 1963 Leszek Prorok o wiele skromniej projektował futurologiczną scenografię:

Przestronne wnętrze. Abstrakcja w architekturze i umeblowaniu. Lampy o niecodziennych kształtach lub skryte dyskretnie źródła światła rozproszonego.

18 Tamże, s. 196.

19 Zob. A. Niewiadowski, Literatura fantastycznonaukowa, Warszawa 1992, s. 247 254.

20 Zob. L. Eustachiewicz, Dramaturgia wspótczesna 1945-1980, Warszawa 1985, s. 244-246.

21 Trzech-wieczny cztowiek, czyli Co bylo, co jest $i$ co będzie? Utwór fantastyczno-czarodziejsko-komiczny $w$ trzech wiekach $z$ niemieckiego przez $K$. Nowińskiego przerobiony ze śpiewami, chorami, ogniami etc., rękopis Biblioteki Raczyńskich w Poznaniu, sygn. T-712, k. 43r. (O obszerniejszą analizę tego utworu pokusiłem się w książce Romantyczna futurologia, Kraków 2005). 
Sprzęty oryginalnej formy i niewiadomego przeznaczenia. Głośnik, tafla telewizora i telefon ukryte $\mathrm{w}$ ścianie. Na stoliczku podręczny, domowy magnetofon. Raz po raz rozlegają się przejmujące, ale raczej przyjemne tony muzyki elektronowej22.

Oddziela od siebie te dwa utwory epoka panoramy, dioramy, potem wielkiej reformy teatralnej i wreszcie narodzin sztuki filmowej, która już zdążyła wtargnąć do teatru. Wychodzi na to, że im większe możliwości techniczne, tym skromniej się $w$ teatrze objawia science fiction. I kto wie, czy doświadczenia mieszczańskiego teatru realistycznego bardziej niż późniejsze groteskowe deformacje nie przyczyniły się do ugruntowania przekonania, że podobnie jak w dramacie historycznym nie trzeba wcale armatnim pociskiem rozsadzać tekturowych murów obronnych, by uwiarygodnić fakt zdobycia twierdzy, tak i spektakl o wizycie kosmitów nie wymaga pokazania lądujących na Ziemi latających talerzy.

Rakieta Thunderbolt Mariana Promińskiego, mimo że pomyślana jako „sztuka telewizyjna w 2 aktach i 12 obrazach", ogrywa start rakiety poza sceną, niczym bitwę w klasycznym dramacie. Nowoczesność i efektowność zapewnia jej decyzja o rezygnacji z relacji posłańca, gwarantująca emocjonalne przeżywanie wydarzenia na bieżąco, lecz $\mathrm{z}$ daleka. Oczom widzów ukazuje się

Hala. [...] Mikrofon na stole. Tablica rozdzielcza, na której wybłyskują światła. Oko radarowe. Radiotelegrafista zmienia wtyki w centralce. - Fragment filmu dokumentalnego ${ }^{23}$.

Napięcie rośnie na skutek problemów z łącznością, uwagę skupia pragnienie usłyszenia głosu pilota, rekompensując niedostatek wrażeń wizualnych.

W Powrocie taty Leszka Proroka rodzina astronauty obserwuje start rakiety przez okno z najzwyklejszego prywatnego mieszkania:

W perspektywie okna wykwita wielki blask. Przedmiot ksztaltu cygara wzbija się w górę, zataczając lekki łuk w stronę górnego narożnika okiennego. Dzieci krzyczą: „Poleciał, tatuś poleciał!”24

Akcja Latajqcych talerzy Władysława Smólskiego rozgrywa się wokół teleskopu umieszczonego w restauracyjnym ogródku. Talerze ukazują się pod postacią majaczących na niebie odległych światełek, obecnych w dodatku tylko w dialogach, nie w didaskaliach. Można zatem przypuszczać, że aktorzy, zwróceni twarzami do widzów, dostrzegają rzeko-

${ }^{22}$ L. Prorok, Powrót taty. Komedia $w 3$ aktach z prologiem $i$ epilogiem, Warszawa 1963, s. 11.

23 M. Promiński, Rakieta Thunderbolt. Sztuka telewizyjna w 2 aktach i 12 obrazach, „Dialog” 1959, nr 7.

${ }^{24}$ L. Prorok, Powrót taty, s. 10. 
me światełka gdzieś ponad ich głowami - tak przeważnie w teatralnych realizacjach Nie-Boskiej Komedii Pankracy ogląda na końcu Galilejczyka-mściciela, nie zobowiązując publiczności do wiary w swoją wizję.

SMITH (obserwujq̨c niebo): Uwaga! Swiatła na niebie!

(Obecni zrywajq się od stolików i otaczajq Smitha)

SMITH: Zbliżają się! Rosną!...

PROFESOR: To „talerze”. [...]

URZĘDNIK: Zniżają lot!

SMITH: Nie ma wątpliwości.

ALICE: To oni! Goście z Wenus! [...]

URZĘDNIK: Opuszczają się.

DZIENNIKARKA: Jak nisko!

SMITH: Słyszycie szum ich motorów? Pst!... [...]

(Stychać przepiękny dźwięk, przypominajqcy brzęk roju pszczót i organy).

TRAMP: Cóż za cudowna muzyka!

BONNY: Niby organy.

ALICE: To harmonia gwiezdnych sfer. [...]

(Nagle stychać brutalny warkot samolotu).

SZOFER: Co to?

URZĘDNIK: Samolot?

RALF: To Eddie na swojej awionetce. Pewnie chce ścigać „talerze”. [...]

DZIENNIKARKA: Popsuł nam caly nastrój.

SMITH: Już polecieli.

SZOFER: Giną na horyzoncie.

BONNY: A szkoda. To było piękne.

WALKER (liczq̨c pieniqdze): Porządni chlopcy, ci z Wenus. Dotrzymali słowa ${ }^{25}$.

Wierny robot Stanisława Lema jest od strony scenograficznej podobnie ascetyczny. Dla Wyprawy profesora Tarantogi zaplanował wprawdzie autor pewne fantastycznonaukowe efekty, lecz one właśnie trącą teatralną starzyzną. Wadliwie skonstruowaną maszynę do teleportacji wyobrażają na przykład dwie skrzynie $\mathrm{z}$ otwieranymi tylnymi ścianami (zapisana $\mathrm{w}$ didaskaliach troska o to, „żeby aktorzy mogli przechodzić z tyłu"26 sygnalizuje nader wyraźnie, że sztuka powstała z myślą o teatrze, nie o telewizji - inna rzecz, że w czasie jej powstania teatr telewizji działał jeszcze dość siermiężnie i nadawał na żywo). Pozostałe „rozmaite efekty dźwiękowe i świetlne", tudzież przelatujące przez scenę przedmioty (równie dobrze mogłyby to być meteory z didaskaliów Lema) stosowano w teatrze już na długo przed wymyśleniem nazwy dla literatury science fiction. W ogóle Wyprawa profesora Tarantogi mogłaby

${ }_{25}$ W. Smólski, Latajqce talerze. Sztuka w 3 aktach, Biblioteczka Repertuarowa Miesięcznika „Kultura i Ty”, 1/1967, s. 28-29.

${ }^{26}$ S. Lem, Wyprawa profesora Tarantogi, w: Noc księżycowa, Kraków 1963, s. 157. 
uchodzić za wzorcowy przykład budowania teatralnej iluzji silnie rozwiniętych cywilizacji środkami „chałupniczymi”. Oto jak przebiega wizyta Tarantogi na „słoncu z gromady Strzelca”:

(Efekty. Pojawia się rodzaj bardzo dziwnego, niskiego stolu. Ma on otwory, w kazdym $z$ tych otworów siedzi jeden Kalenusjanin. Razem jest ich trzech. Twarzami zwróceni sq ku sobie. Powierzchnia stolu między nimi pokryta jest bogatymi deseniami. Ponadto znajdujq się $w$ niej rozmaite zamknięte na razie klapki. Kalenusjanie, podobni do ludzi, sq catkiem lysi, na tych łysinach mogq mieć różne rzeczy, np. dodatkowe uszy, nosy czy anteny) [...]

KALENUSJANIN II: [...] Halo! Proszę mnie połączyć z Wyklękiem! Halo, Wytwórnia Klęsk i Katastrof? Tu Tajny Międzykozak. Jak? Nie słychać? Tajny Międzykozak, mówię. Tajny Międzyresortowy Komitet Zatrważania Konstruktywnego... Tak. Halo! Jest tam główny inżynier? Dawać go tu!

(Kalenusjanin I naciska guzik. W stole otwiera się klapka, wychyla się przez niq glowa inżyniera). [...]

KALENUSJANIN II: Uważam, że zamiast dyskutować, powinniśmy się raczej zlać. Inaczej nie opracujemy niczego do świtu.

KALENUSJANIN I: Zgoda! Koledzy, zlewamy się! [...]

(Wyciaga skqdś giętkq rurę, przystawia jq̨ do głowy Kalenusjanina II, a drugi koniec przystawia sobie do czoła).

PROFESOR: Panowie, przepraszam was najmocniej! Mam wrażenie, że jesteście obywatelami planety Kalenusji...

KALENUSJANIN I: Nie przeszkadzać! Konferencja! Eufrozy, nie czuję jeszcze twojej świadomości. [...] O tym, że chce pan tu dziś wleźć i przeszkadzać, wiedzieliśmy już trzy tygodnie temu. [...] (do mikrofonu) Dawać tu Mały Mózg.

( $Z$ boku wysuwa sį̨ coś $w$ rodzaju ściany wyobrażajqcej mózg elektronowy. Może mieć pewne podobieństwo do groteskowej twarzy, różne zegary, światla, glośniki itp.)

KALENUSJANIN I: Podaj ostatnie doniesienia z Ziemi.

MOZZ: Jak donosi Kalenusjańska Agencja Kosmiczna, niejaki Tarantoga, przedstawiciel słabo rozwiniętej rasy istot podmyślących, buduje od trzech tygodni domowym sposobem pierwszy ziemski teletaktor. [...]

KALENUSJANIN I: Wystarczy. [...] Panie włochaty, żegnam!

PROFESOR: Ależ, panowie, tak nie można przecież...

KALENUSJANIN II: Nie ma rady. Podajcie mi glowociąg!

(Otwiera się w stole klapka, ręka podaje głowociqg). [...]

CHYBEK: Panie profesorze, on celuje!

(Profesor wytq̨cza. Trochę dymu, może być blysk i wszystko znika) ${ }^{27}$.

Czyli do przedstawienia odległej, a technicznie zaawansowanej cywilizacji wystarczy miotacz dymu, dziurawy stól, giętka rura i ruchoma ściana - „głowociąg” może wyglądać dowolnie, bo i tak nie wiadomo, do czego miał posłużyć.

27 Tamże, s. 147-152. 
Można by sądzić, że latwiej w gruncie rzeczy zaprezentować świat na tyle odległy od potocznie doświadczanej rzeczywistości pozaliterackiej, że przybierający kształt świata baśniowego (czyli to, co Caillois określił nazwą science fiction, w odróżnieniu od fantastyki, która realizuje typ zakłóconej czy udoskonalonej normy) - człekokształtnego robota najwyższej generacji może przecież zagrać żywy aktor, trudniej zaś wprowadzić na scenę prymitywną maszynę, która, będąc stalową konstrukcją połączoną kablami i ozdobioną żarówkami, powinna może jeszcze zgrzytać i dymić.

A jednak Pawlikowska-Jasnorzewska potrafiła zbudować sceniczny świat ulepszonej normy także za pomocą scenicznych rekwizytów - co, z drugiej strony, sprawiło zapewne, że sztuka szybko się zestarzała. Dziś już tylko wzruszać mogą swą naiwnością takie neologizmowe rekwizyty, jak na przykład radiofon - „skrzynka fantastyczna w ścianie"28, której fantastyczność polega, zdaje się, na tym, że w przeciwieństwie do tradycyjnego telefonu nie jest wyposażona w słuchawkę, albo astrodaktyl „maszynka fantastyczna $\mathrm{z}$ dzwonkiem"29, która zastąpiła maszynę do pisania. Ciekawe, że urządzenia te mają „wystąpić” na scenie, w działaniu, mimo że ich znaczenie dla rozwoju akcji jest znikome (może to celowe zabezpieczenie, na wypadek gdyby inscenizator je pominął). Pojawia się także swoisty „rekwizyt” świetlno-dźwiękowy - przyjazd taksówki sygnalizowany jest $\mathrm{w}$ ten sposób, że „za oknem przesuwa się szybko cień. Słychać szum"30. Dźwięki sugerują udoskonalenie parametrów technicznych pojazdu silnikowego i wszystko wskazuje na to, że chodzi o pojazdy latające (przesuwają się za oknem, a mieszkanie usytuowane jest w jakimś monstrualnym wieżowcu, w którym wymienione w rozmowie piętro 185 nie jest chyba jeszcze ostatnim). Wynalazki niepokazywalne istnieją zaś na sposób literacki - w nazwach stacji powietrznych, kolei podziemnej - niekiedy pod postacią neologizmu typowego dla science fiction: budowa słowotwórcza aerocykla ułatwia widzowi bądź czytelnikowi jego wyobrażenie jako powietrznego motocykla, andremedon natomiast, który jest pojazdem dużo większym, bo nie mieszczącym się w gęstej zabudowie, potęgować ma właśnie odczucie obcości kreowanego świata. Obydwa przeciwstawne sobie mechanizmy nazywania fantastyka naukowa stosuje $\mathrm{z}$ upodobaniem ${ }^{31}$.

28 M. Pawlikowska-Jasnorzewska, Kochanek Sybilli Thompson, w: Dramaty, oprac. A. Bolecka, wstęp S. Treugutt, Warszawa 1986, t. I, s. 123.

29 Tamże, s. 117.

30 Tamże, s. 129.

31 Zob. R. Handke, Językowe sposoby kreowania sktadników fantastycznych, w: Polska proza fantastycznonaukowa. Problemy poetyki, Wrocław-Warszawa-Krak6w 1969. 
Ze względu na tego typu zabiegi forma dramatyczna objawiać powinna szczególną atrakcyjność. Wymagana w niej skrótowość i związana z nią selekcja materiału znakomicie uzasadnia przemilczenia z trudem tolerowane w epice. Racjonalistyczne, naukowe uzasadnienie - niezbywalny składnik każdego utworu science fiction - także potrzebuje swoistych „miejsc niedookreślenia”, oscylując pomiędzy nauką i fantastyką. I to niemal na każdym kroku. W początkach swego istnienia literatura fantastycznonaukowa borykała się na przykład z problemem kosmicznego środka transportu. Bohater odbywał podróż na księżyc albo we śnie hipnotycznym lub w stanie śmierci klinicznej (T. Tripplin, Podróż po Księżycu odbyta przez Serafina Bolińskiego, 1858), albo balonem, przesypiając całą podróż (M.D. Krajewski, Wojciech Zdarzyński, życie i przypadki swoje opisujacy, 1785), albo też balonem (E.A. Poe, Nieporównana przygoda niejakiego Hansa Pfaalla, 1835) bądź w pocisku (J. Verne, Wokót Księżyca, 1865), dokonując pseudnaukowego zapisu podróży z naturalistyczną dokładnością i dużym ryzykiem szybkiej weryfikacji fantastycznych pomysłów przez nowe naukowe odkrycia. W teatralnym skrócie wehikuł profesora Tarantogi jednocześnie zaspokaja i pobudza ciekawość, nie pozwalając się zarazem traktować zbyt poważnie:

PROFESOR: Żadnej rakiety nie będzie. Młody człowieku, proszę uważnie słuchać: odkryłem nowy sposób podróżowania w Kosmosie!

CHYBEK: Nowy? A rakieta?

PROFESOR: Bez rakiety. Moją rakietą można przenosić się z miejsca na miejsce bez jakichkolwiek pojazdów, okrętów, samolotów czy statków gwiazdowych... [...] Księżyc i Ziemia znajdują się w przestrzeni. W trójwymiarowej przestrzeni. Przestrzeń tę zginam. Mój aparat składa ją we dwoje, w czwartym wymiarze, aż nastąpi styk punktu wyjściowego z punktem docelowym... [...] Pole grawitacyjne ulega ściśnięciu, limitowanemu obojnaczo wyznacznikami Lorentza-Fitz-Geralda, ma się rozumieć kowariantnie, wzdłuż geodezyjnych...

CHYBEK: Nie rozumiem.

PROFESOR: To nic $^{32}$.

Tarantoga stosuje w swym wykładzie skróty myślowe czytelne tylko dla niego samego, więc jego „naukowa" metoda pozostaje w praktyce pozaliterackiej nieweryfikowalna. Asystent Chybek, dzięki temu, że zatrudniony został dopiero jako towarzysz podróży i nie uczestniczył w przygotowaniach ani w pracach nad skonstruowaniem aparatu - reaguje w imieniu widza. I potraktowany zostaje jak widz - nie musi rozumieć wszystkich szczegółów, wystarczy, by przyjął do wiadomości, iż cały skomplikowany proces, który przenosi do mieszkania Tarantogi fragmenty odległych galaktyk, pozwala się racjonalnie wytłumaczyć. W re-

32 S. Lem, Wyprawa profesora Tarantogi, s. 140-142. 
zultacie dekoracja się zmienia, ale widz towarzyszy podróżnikom nieustannie i nie jest zbywany relacjami o starcie i lądowaniu rakiety, które musiałyby następować podczas antraktów. Tym sposobem jedność czasu i miejsca zostaje równocześnie naruszona (literacko) i zachowana (teatralnie). Dalej, w podobnie teatralnym skrócie i ze sporą dozą dowcipu, przedstawia Lem na kolejnych planetach wszystkie niepokoje określające kondycję człowieka w tym ostatnim - wedle podziału Caillois - etapie historii, w którym filozofia cywilizacji straszy groźbą chorób z ułatwienia, masowej zagłady i zalania ubocznymi produktami cywilizacyjnego postępu ${ }^{33}$.

Wszakże w sposobie prezentacji świata fantastycznego Wyprawa profesora Tarantogi skonstruowana jest na tej samej $-\mathrm{z}$ utopii przejętej - zasadzie, co futurologiczna drama Meisla z początku XIX wieku - w kolejnych „odsłonach" poszczególne światy są pokazywane i „opowiadane”. Tej prezentacji podporządkowana zostala akcja. (Dziwny gość profesora Tarantogi prezentuje świat przyszłości już tylko w słownej relacji przybysza, a niedostatki naukowych objaśnień tłumaczy fakt, że trafił się profesorowi osobnik akurat niezbyt rozgarnięty).

Jak ciekawy efekt przynieść może zabieg odwrotny - upodrzędnienie fantastyki naukowej w stosunku do akcji - pokazuje dramat Leszka Proroka. Gdy astronauta Adam Hust trafia - jak sądzi, po upływie kwartału, a w rzeczywistości po sześćdziesięciu latach - do swojego mieszkania, wpada nagle w wir codziennego życia swoich dalekich potomków, którzy początkowo nie zwracają uwagi na dziwnie wyglądającego, obcego przybysza, biorąc go za jednego $\mathrm{z}$ aktorów, zapraszanych niekiedy do domu przez sentymentalnego dziadka. Dziadek okazuje się synem pozostającego w sile wieku Adama. Dopiero z końcem pierwszego aktu następuje anagnorisis. Scena rozpoznania, która w klasycznym dramacie przyniosłaby rozwiązanie konfliktu, w Powrocie taty prawdziwy konflikt właśnie wywołuje (zmiana funkcji klasycznego chwytu przywołuje na myśl konstrukcję IV części Mickiewiczowskich Dziadów). Odtąd akcja koncentruje się wokół motywu, jakiego nie powstydziłaby się antyczna tragedia - kazirodczej miłości Adama do jego prawnuczki Izoldy. Miłości zresztą odwzajemnionej, gdyż - inaczej niż w dramacie Pawlikowskiej - staroświeckie zaloty oczarowują młodą dziewczynę szybko i skutecznie. Nawet sędziwa Elżbieta, starsza córka Adama, surowa, wręcz bezwzględna w swoich decyzjach, gwałtowny wybuch grzesznej namiętności potępia, ale potrafi zrozumieć, gdy spogląda na niemrawych, niezdolnych do szaleńczych porywów rówieśników Izoldy.

${ }^{33}$ Zob. J. Bańka, Filozofia techniki. Czlowiek wobec odkrycia naukowego i technicznego, Katowice 1980. 
ELżBIETA: [...] Co się z naszą młodzieżą porobiło. Nic w niej werwy. Przyznać muszę, że ojciec na tym tle prezentuje się szczególnie ciekawie. Co racja, to racja. Trudno się nawet tej malej dziwić. Gdyby nie to, że w linii prostej... Brrr... ${ }^{34}$

Przebieg głównego wątku nabiera cech tragikomicznych. Adam tłumi miłosne uniesienia Izoldy słowami: „nie przy dzieciach”, wskazując przy tym na siwych staruszków, dziadków swej kochanki, jednocześnie Jan i Elżbieta, obserwując zapędy własnego ojca, wzdychają: „ci młodzi mężczyźni”. Komizm słowno-sytuacyjny rodzi jednak - jak widać - tylko sama podstawa konstrukcyjna związana z motywem "przerzucenia” bohatera w przyszłość. Pamięć o niej podtrzymują mimochodem podrzucane informacje na temat organizacji świata przyszłości. Wiadomość o opanowaniu sił przyrody dociera do świadomości odbiorcy tylko dlatego, że Izolda wymienia nazwę Instytutu Wywoływania Deszczu, w rozmowie z Adamem młody przyjaciel Izoldy - Karol - wspomina coś o sztucznej produkcji (właściwie już nadprodukcji) ludzi (z probówek) i o poprawkach zaprowadzonych $w$ atmosferze Marsa. Zdezorientowany początkowo Adam, a z nim razem widz - musi za tym nadążyć i siłą rzeczy zgodzić się na konstruowanie obrazu świata głównie we własnej wyobraźni, a przy tym pamiętać, że „z tych kawałków trudno będzie”. Na scenie zobaczy tylko egzotyczne ubrania, których kroju zresztą wskazówki inscenizacyjne nie określają precyzyjnie, a z dialogów wynika, że mają być wygodne, przewiewne i wykonane $\mathrm{z}$ przędzy aluminiowej ( $\mathrm{w}$ młodzieńczej powieści Verne'a - Paryż $w X X$ wieku - przędza miała być żelazna niby drobiazg, a o znaczeniu epokowym).

Niektóre elementy świata spoza scenicznego mikrokosmosu pozostają - zgodnie $\mathrm{z}$ regułami fantastyki naukowej - scharakteryzowane tylko poprzez slowotwórczą budowę ich nazwy. Usprawiedliwieniem dla ich niedookreślenia staje się fakt, że np. nukleobus czy globowizja wymieniane są w rozmowie toczącej się pod nieobecność przybysza z przeszłości - pozostali bohaterowie nie muszą, nawet nie mogą tłumaczyć sobie, czym są urządzenia, do których zdążyli już przywyknąć.

Ciekawszym jednak - bo i rzadziej stosowanym, i chyba zabawniejszym - chwytem wydaje się zasada zawiedzionego oczekiwania, realizowana w przyszłościowej frazeologii. Na przykład:

ADAM: [...] (wychyla się przez okno) Izoldo! Izoldo! Gdzie jesteś?

MARTA: [...] Juź weszła na orbitę i tyle jej widać.

ADAM: Jak to na orbitę? Poleciała rakietą? Dokąd? Kiedy?

MARTA: Ależ pan dosłowny. Aż obrzydzenie bierze. Jaką znów rakietę? Tak się tylko mówi dla fasonu. Pojechała metrem do tej tam przyjaciółki³5.

${ }^{34}$ L. Prorok, Powrót taty, s. 62.

${ }^{35}$ Tamże, s. 22-23. 
Albo:

ILONA: [...] Zaraz będą truskawki. (do Adama) Nasza sąsiadka przywozi zawsze pyszne owoce. Pojechała rano do trzeciego satelity. [...]

ADAM: [...] (do Ilony) Przepraszam, powiedziala pani: do trzeciego satelity. Nie rozumiem - w kosmos?

ILONA: Ach nie. Chodzi o satelitę miejskiego. Jest kilka osiedli wokół miasta. Trzeci satelita słynie $z$ dobrych owocó $w^{36}$.

W końcu - ileż mogło się zmienić w ciągu zaledwie sześćdziesięciu lat? Drobne poprawki atmosfery Marsa - owszem, ale żeby zaraz kosmiczne plantacje owoców! Jest jedną z naczelnych prawidłowości literatury fantastycznonaukowej, że ,jakościami weryzmu czy realizmu, mocno sugestywnymi, są utwory nasycone tym lepiej i gęściej, im bliższa jest ich czasowo przestrzenna lokalizacja względem ziemskiej teraźniejszości"37. A jednak prawidłowość tę Stanisław Lem odnotowuje bez przesadnego entuzjazmu. Rozsądny umiar stanowi najwyższą cnotę w oczach ortodoksyjnych wyznawców fantastyki typu verne'owskiego. Pociąga on jednak za sobą ryzyko szybkiej weryfikowalności prognoz. Jak słusznie zauważa Juliusz Kadz Palczewski, „większość konkretnych pomysłów Verne’a dognała, wchłonęła i prześcignęła rzeczywistość”38. Podobnie rzecz ma się z fantastyką przestrzenną, którą uśmierca minimalna choćby dawka naukowej wiedzy o budowie planet - zwracał na to uwage Michel Butor:

Wiadomo, że ciążenie na Wenus jest większe, a na Marsie mniejsze niż na Ziemi itd. Tych kilka danych zmusza respektującego je pisarza do ogromnego wysiłku wyobraźni. [...]

By nie przyznać się do porażki, trzeba brnąć dalej. Zamiast opisywać coś, co mogłoby się rozgrywać na Marsie i Wenus, lepiej od razu przeskoczyć na trzecią planetę systemu epsilon Łabędzia lub też, skoro naprawdę nic nie przeszkadza pozostać na tak dobrej drodze, aż na planetę $\mathrm{N}$ gwiazdy $\mathrm{N}$ galaktyki $\mathrm{N}$. [...]

Taka nieograniczona swoboda jest tylko pozorna. Jeśli ktoś bez końca ucieka w daleką przestrzeń lub czas, to w końcu znajdzie się na obszarze, gdzie wszystko jest możliwe, gdzie nie będzie już trzeba nawet zadawać sobie trudu koordynowania wytworów wyobraźni. W rezultacie powstanie zubożone powtórzenie codziennej rzeczywistości. Opowiada się nam o wielkiej wojnie pomiędzy cywilizacjami galaktycznymi, lecz bardzo szybko zauważamy, że liga demokratycznych planet dziwnie przypomina ONZ [...]. Autor jedynie przetłumaczył na język SF artykuł z przeczytanej poprzedniego wieczoru gazety ${ }^{39}$.

36 Tamże, s. 40.

${ }^{37}$ S. Lem, Fantastyka i futurologia, Warszawa 1996, t. II, s. 140.

38 J.K. Palczewski, Wstęp, do: H.G. Wells, Wehikut czasu, przeł. F. Wermiński, BN II 216 , Wrocław 1985 , s. X.

${ }^{39}$ M. Butor, Kryzys rozwojowy science fiction, przeł. B. Okólska, w zbiorze: Spór o $S F$, s. 44-45. 
Kategoryczny ten sąd należałoby może złagodzić zastrzeżeniem, że zubożone „powtórzenie codziennej rzeczywistości” grozi przede wszystkim autorom miernym, którzy w szacie fantastyki naukowej uprawiają prymitywną publicystykę przyprawioną domieszką sensacji. Nikt by tego przecież nie powiedział o utworach Lema, który także umieszcza swych bohaterów $\mathrm{w}$ odległych galaktykach, lecz czyni to $\mathrm{z}$ całą świadomością reguł gatunku, traktowanych $\mathrm{z}$ wyraźnym dystansem. Wszakże $\mathrm{i}$ w tej prostej publicystyce odtwarzany na innych planetach model ziemskiej cywilizacji może być nie tylko zubażany, ale i przekształcany, wzbogacany lub odwracany. Podobnie w przeszłości traktowany był taki model sytuowany na nieznanych odległych wyspach któregoś $\mathrm{z}$ oceanów. Po to właśnie pisano utopie, by się w nich świat realny przeglądał.

Tymczasem istotny pozostaje zasięg przestrzeni zbyt dobrze naukowo rozpoznanej w konkretnym momencie historycznym. Najwyraźniej u progu lat trzydziestych XX wieku stary poczciwy Księżyc - tak silnie eksploatowany $w$ dziewiętnastowiecznej fantastyce - znajdował się już za blisko.

Anonimowy autor Wyprawy w zaświaty - „sztuki fantastycznej” zachowanej $w$ archiwum Zegadłowicza - ulokował swoją utopię na Marsie, gdzie trzej ziemscy śmiałkowie - prof. Gwiaździński (astronom), dr Główski (,inżynier-technik”) i dr Radiolski (chemik) zlądować mieli w roku 2000 (Radiolski spotkał tam swą przyszłą żonę, a Gwiaździński rodzonego ojca, który zaginął w kosmosie dwadzieścia pięć lat wcześniej).

Wyprawa $w$ zaświaty mogłaby wręcz uchodzić za wzorcowy przykład braku teatralnej wyobraźni. Na trzydzieści dwie strony maszynopisu przypada dziewiętnaście aktów, podzielonych na sceny, wymagające nieustannych zmian miejsca akcji; przewiduje także przygotowania do startu rakiety i sam start $\mathrm{z}$ dachu budynku, niemal jednocześnie obserwowany $\mathrm{z}$ ulicy na dole (porównanie może trochę niestosowne, lecz podobne „akrobacje" przestrzenne projektował Wyspiański - choćby w Legionie), poza tym lądowanie rakiety ( $\mathrm{z}$ której wysiadają astronauci), przenośne aparaty latające, miękkie rozciągliwe szkło w ramach okiennych, a także operację odmładzającą.

W Kochanku Sybilli Thompson Pawlikowskiej-Jasnorzewskiej naukowo-magiczny proces odmłodzenia tytułowej bohaterki siłami życiowymi czerpanymi z sześciu młodych tancerek odbywa się za zamkniętymi drzwiami, a jednocześnie ogrywany jest teatralnie wąsiednim pokoju, czyli na scenie, gdzie z półek spadają książki, a pielęgniarka Nurse uspokaja czekającą na Sybillę gosposię:

NURSE: [...] To są dodatkowe objawy seansu, który się odbywa w przyległej sali. Dawniej myślano, że to duchy! Nazywano to straszeniem. Dzisiaj wiemy, że jest 
to tylko rozruszanie atomów materii przez fale ondyczne, składową część żywych organizmów ${ }^{40}$.

W epoce, w której literatura przestała się już wstydzić swej literackości, a teatr teatralności, wolno było tego rodzaju efekty przedstawiać także na scenie, z podkreśleniem kreacyjnego charakteru świata przedstawionego - jak to uczynił Winawer w Promieniach $F F$, zapisując po prostu w didaskaliach, że Serafin, szalony naukowiec i cudotwórca, „zdejmuje z Ewy perukę, ściera jej zmarszczki z twarzy"41. Cóż, kiedy autor Wyprawy $w$ zaświaty wybrał naturalistyczny obraz interwencji chirurgicznej. Posunął się nawet dalej i postanowił pokazać - także w klimacie szpitalnej sali - operację stworzenia sztucznego marsjańskiego obywatela II klasy, który początkowo leży na stole „nieżywy, jakby ze skóry obdarty”, a pod wpływem powleczenia ciała masą, która „szybko twardnie[je] i różowieje, i tworzy skórę człowieka” - natychmiast „podnosi się ze stołu i mówi”. Tego rodzaju tricki możliwe są już tylko w filmie, i to pod warunkiem zastosowania animacji komputerowej. Warto przypomnieć, z jak silnym poczuciem niepodobieństwa scenicznego wykonania Winawer odnotowal w didaskaliach zwykły rumieniec:

staje się raptem cud, który tylko chyba w Biblii, albo w dobrym teatrze jest możliwy. Serafin płonie rumieńcem, innymi słowy zaczyna świecić czerwonym światłem, jakby kto nań reflektor teatralny skierował ${ }^{42}$.

Spotęgowanie rumieńca do mocnego efektu świetlnego ze sfery cudowności wyprowadza - zgodnie z prawami fantastyki naukowej - realistyczna wykładnia. Proces ten przebiega jednak nie $w$ planie świata przedstawionego, a w każdym razie nie we wszystkich jego planach. Jeśli bowiem Serafin oświadcza na końcu: „Przed przyjściem tutaj zawarłem umowę $z$ elektrotechnikiem teatralnym. On na mnie kieruje reflektor, a ja świecę"43 - to właściwym planem realistycznej wykładni okazuje się sytuacja teatralna, potraktowana literacko. Porównując styl komedii naukowych Winawera i Cwojdzińskiego, stwierdza Sylwia Wójcikowa, że „to, co mówi o nauce w swoich utworach Winawer jest bardziej dramatyczne (jakby literackość podkreślała atrakcyjność przekazu). Zaś to, co mówi Cwojdziński w swoich komediach, jest nienaganne z punktu widzenia rzemiosła teatralnego" ${ }^{44}$. Anna Krajewska dodaje, że w Promieniach FF (komedii de facto nie tyle naukowej, co fantastycznonaukowej) „cu-

${ }^{40}$ M. Pawlikowska-Jasnorzewska, Kochanek Sybilli Thompson, s. 157.

41 B. Winawer, Promienie FF, s. 27.

42 Tamże, s. 15.

43 Tamże, s. 92.

44 S. Wójcikowa, op. cit., s. 134.

233 O teatrze science fiction kilka uwag 
downość ma [...] rodowód literacki i teatralny"45. Sygnały teatralnego rodowodu fantastyki nie mają jednak (może poza ostatnią wypowiedzią Serafina) charakteru ostatecznego, kategorycznego. Docierają do odbiorcy raczej pod postacią sugestii niż informacji. Jeśli groteskowy charakter utworów Lema zasadza się na przełamaniu praw tradycyjnej science fiction $^{46}$, to $\mathrm{w}$ komedii Winawera następuje raczej naruszenie reguł teatralnej komunikacji, ale zarazem wewnątrztekstowa świadomość sytuacji teatralnej sama w sobie już stanowi przełamanie reguł literatury fantastycznonaukowej, poprzez natrętnie manifestowaną iluzyjność świata przedstawionego. Można odnieść wrażenie, że teatralność i fantastyka nieustannie walczą tu o pierwszeństwo i każda $\mathrm{z}$ nich próbuje widzom własnymi plecami zasłonić rywalkę. Czy można - z drugiej strony - wyobrazić sobie harmonijną ich współpracę - taką, która by do każdej sfery wnosiła coś nowego i twórczego? Bo przyznać trzeba, że omawiane dotychczas zagadnienia i przykłady wskazywały raczej na problematykę respektowania wynikających $\mathrm{z}$ tego układu ograniczeń. Prawdopodobnie mozolne poszukiwania pozwoliłyby w rezultacie sporządzić niewielki katalog drobiazgów - takich na przykład, jak historia pewnego rekwizytu.

Anna Krajewska zauważyła na poły żartobliwie, że w naukowych komediach dwudziestolecia do rangi bohatera scenicznego urasta telefon, co ma swoje konsekwencje dla konstrukcji dramatu i jego inscenizacji. W Powrocie taty Leszka Proroka fantastycznonaukowy rekwizyt wpływa także na język postaci, które używają wyrażenia: „odsłuchać list”. Rekwizytem tym jest magnetofon, najpewniej szpulowy, skoro mowa o „krążkach”. Właściwie to owym rekwizytem-bohaterem staje się sam „krążek”, taśma nawinięta na szpulę. Sztuka pochodzi z 1963 roku, a więc fantastyczność rekwizytu tkwi w jego zastosowaniu, w zmianie funkcji. I faktycznie "list odsłuchiwany" sprawdza się na scenie - dzięki niemu nie trzeba stosować skomplikowanych manewrów uzasadniających głośne oczytanie listu lub przypadkowe zapoznanie się przez którąś z postaci $\mathrm{z}$ listem adresowanym do kogoś innego (w II akcie Elżbieta przypadkowo słyszy początek wiadomości Karola przeznaczonej dla Izoldy, bez konsekwencji jednak dla rozwoju akcji). Szkopuł w tym, że historia tego rekwizytu jest od strony fantastycznonaukowej zupełnie niewiarygodna. Nie tylko dlatego, że widzowie Powrotu taty od lat już używali telefonów. Fantastyka naukowa domaga się racjonalizmu i praktycyzmu - także życiowego. A list nagrany na taśmę - w porównaniu $z$ tradycyjnym listem pisanym - jest po prostu niewygodny, bo nie dość, że jego postać materialna bardziej krucha, to jeszcze wymaga zastosowania dodatko-

45 A. Krajewska, op. cit.

${ }^{46}$ Zob. R. Handke, op. cit. 
wego urządzenia, które nie zawsze można mieć pod ręką. Taśma magnetofonowa powstała przecież $\mathrm{w}$ innym celu $-\mathrm{z}$ myślą o utrwalaniu i przechowywaniu, nie zaś o łatwości i szybkości komunikacji. Jest ponadto cięższa od złożonej kartki papieru zamkniętej w kopercie, a jak wynika z dialogu bohaterów Powrotu taty - „listy” przeznaczone do odsłuchania przesyłane są zwyczajnie, za pośrednictwem poczty. Tego rodzaju pomysły - mimo swej doraźnej atrakcyjności - na dłuźszą metę umacniają raczej powszechnie panujące przekonanie, że futurologia i fantastyka naukowa do teatru... jakoś nie pasuje. 